\title{
TUHAN YANG TIDAK DISEMBAH DAN MATI
}

\author{
Sugiyarto \\ Prodi Sastra Indonesia Universitas Pamulang \\ Sugihwarto@yahoo.com
}

\begin{abstract}
Abstrak
Di Jember Jawa Timur ada enam orang bernama Tuhan, satu di antaranya sekarang sudah meninggal. Nama ini dipermasalahkan karena dinilai tidak lazim, menodai, dan sirik. Pemilik nama Tuhan diancam diboikot hak-hak sipilnya bila tidak mau mengganti namanya. Permasalahan ini sudah berulang setiap menjelang pesta demokrasi. Penelitian ini mengungkap fakta-fakta lain tetang nama Tuhan yang bersifat ilahiah dan insaniah, sehingga bisa membuka pengetahuan baru tentang nama Tuhan. Selanjut bisa dipakai untuk landasan bersikap dan bertindak dalam memandang dan mendudukan persoalan nama Tuhan pada insaniah ini. Peneliti menggunakan metode diskriptif dengan pendekatan etimologi, morfologi, semiotik, dan tradisi lisan. Peneliti juga melengkapi dengan mengaji dasar-dasar hukum penggunaan nama untuk orang. Hasilnya, tidak ada pelanggaran hukum yang dilakukan oleh pemilik nama Tuhan. Selain itu juga tidak ada unsur sirik dan menodai keagungan Tuhan, namun justru sebagai pewaris sejati bahasa leluhur Jawa.
\end{abstract}

Kata Kunci: Tuhan, Tuan, Jember, Semiotik

\section{Pendahuluan}

Nama Tuhan menjadi perbincangan hangat masyarakat menjelang Pemilihan Presiden dan berlanjut hingga ke Pemilihan Kepala Daerah Kabupaten Jember beberapa waktu lalu. Tercatat, ada enam orang bernama Tuhan dalam Daftar Pemilih Tetap (DPT) dalam pesta demokrasi. Satu Tuhan kemudian meninggal dunia. Masyarakat terhenyak, kemudian memberikan reaksi berbagai macam terhadap munculnya enam orang bernama Tuhan di Jember ini. Hal ini terjadi karena selama ini dalam pandangan masyarakat Indonesia, nama Tuhan itu dinilai sakral dan agung, tidak lazim dipakai sebagai nama orang.

Kamus Besar Bahasa Indonesia (KBBI) juga meneguhkan keyakinan masyarakat tersebut, dengan memberi devinisi Tuhan adalah sesuatu yang diyakini, dipuja, dan disembah oleh manusia sebagai yang Mahakuasa, 
Mahaperkasa. Sementara kenyataan yang ditemukan di Jember, Jawa Timur, Tuhan itu manusia biasa, orang kampung yang bekerja seperti masyarakat pedesaan pada umumnya; ke sawah, mencangkul, mencari rumput, dan butuh bersosialisasi dengan anggota masyarakat yang lain.

Bagi pemilik nama Tuhan, selama ini tidak ada masalah. Masyarakat sekitarnya juga tidak ada masalah dan tidak mempermasalahkan. Mereka hidup berdampingan tanpa mengundang friksi dengan para tetangganya. Pemilik nama juga tidak merasa terbebani dengan kesakralan dan keagungan nama Tuhan yang disandangnya. Semua itu sudah berlangsung puluhan tahun, dari Tuhan lahir, besar, berkeluarga, beranapinak, hingga memasuki usia senja, bahkan ada yang sudah sampai ajalnya. Fakta di lapangan yang dilaporkan berbagai media massa, Tuhan di Jember rata-rata sudah manula, bahkan kemudian sudah ada yang mati. Ini artinya perjalanan hidup mereka di masyarakat sudah panjang, puluhan tahun, dan selama ini tidak ada masalah dengan nama tersebut.

Baru belakangan ini nama mereka menjadi masalah dan dipermasalahkan setelah tersebar luas di media massa, kemudian ramai diperbincangkan di berbagai platform media sosial. Masyarakat luas banyak yang memprotes dan mempermasalahkan namanya. Tuhan dinilainya tidak layak dipakai sebagai nama orang. Permasalahan tambah serius ketika lembaga sekelas MUI ikut memvonis bahwa nama Tuhan yang mereka sandang tidak cocok. “...Tuhan baik, tapi enggak cocok untuk nama. Itu mensyirikkan nama Tuhan, karena Tuhan kan zat yang disembah, tidak sesuai. Penodaan," kata Ketua Umum MUI Jawa Timur KH Abdusshomad Bukhori kepada wartawan di Hotel Garden Palace Surabaya, Senin, 24 Agustus 2015, sebagaimana dikutip Tempo.co.

Tidak hanya sampai di situ, Ketua MUI Jawa Timur juga sampai memaksa Tuhan menganti namanya atau menambahkan namanya. Bila itu tidak dilakukan, pemilik nama Tuhan diancam tidak memperoleh layanan pemerintah. "Disadarkanlah untuk menambah namanya. Jadi biar sementara tidak dapat mengakses layanan pemerintah, sampai dia mengganti namanya," kata Ketuan MUI Jawa Timur (Tempo.co, 24 Agustus 2015). 
Ancaman dan paksaan MUI Jawa Timur tersebut memang baru sebatas verbalisme, belum sampai pada tindakan. Pun demikian dengan protes massa, baru sebatas disampaikan di media sosial. Tidak disampai secara langsung kepada pemilik nama Tuhan. Hanya saja permasalahan ini tidak bisa kemudian dianggap selesai. Melihat polanya, tidak menutup kemungkinan akan terulang lagi di masa mendatang. Seperti pola yang telah terjadi, pada tahun 2015, masalah nama Tuhan ini sudah mengemuka saat menjelang pemilihan Kepala Daerah. Masyarakat sudah ramai mempermasalahkan, namun kemudian reda dan hilang dengan sendirinya seiring dengan selesainya Pilkada. Tahun 2019 kembali ramai diperbincangkan dan dipermasalahkan saat menjelang Pemilihan Umum (Pemilu) Presiden. Kemudian berlanjut ramai dan dipermasalahkan lagi menjelang Pilkada 2020. Melihat polanya ini, tidak menutup kemungkinan di masa mendatang akan dipermasalahkan lagi. Bahkan ada kemungkinan reaksi yang lebih jika pemilik nama Tuhan belum juga belum mengganti namanya.

\section{Metode Penelitian}

Penelitian ini menggunakan pendekatan kualitatif diskritif. Metodenya adalah kajian pustaka, analisis etimologi, morfologi, semiotik, dan tradisi lisan.

Kajian pustaka kami pakai untuk menelusuri asal-usul kata Tuhan yang kami jadikan objek kajian ini. Analisis etimologi dan morfologi, dipakai untuk menganilis pembentukan kata Tuhan beserta proses perubahannnya.

Pendekatan kajian lisan untuk mengumpulkan informasi secara lisan dari masyarakat sekitar dan pemilik nama Tuhan, mencatat, dan kemudian mendiskripsikannya untuk memperoleh gambaran, baik kehidupan masa lalu maupun kehidupan masa kini dari orang-orang yang bernama Tuhan di Jember ini. Untuk keperluan ini, peneliti tidak turun langsung ke lokasi, tetapi meminta bantuan awak media jaringan Kompas Gramedia yang terdekat ke lokasi dan diperkaya hasil bacaan liputan berbagai media massa. Dari data yang peneliti dapat dan diskripsikan, kemudian peneliti menafsirkan dan maknainya dengan pendekatan semiotik. 


\section{Pembahasan}

\section{Dasar Hukum}

Sebelum kami menganilisis masalah penggunaan nama Tuhan sebagaimana kasus di Jember dengan disiplin cabang ilmu linguitik, yakni melalui tinjau etimologi, morfologi, dan semiotik, yang diperkaya dengan penelitian tradisi lisan, kami ingin menyampaikan dasar-dasar hukum penggunaan nama bagi seseorang warga. Sebab penggunaan nama itu menyangkut hak sekaligus kewajiban bagi setiap warga Negara Indonesia yang dilindungi oleh undangundang.

Dari hasil penelusuran undang-undang yang mengatur penggunaan nama, peneliti menemukan Undang-Undang No. 39 Tahun 1999 tentang Hak Asasi Manusia, Pasal 53 ayat (2). Dalam undang-undang tersebut dinyatakan:"Setiap anak sejak kelahirannya. berhak atas suatu nama dan status kewarganegaraan." Undang-Undang No. 23 Tahun 2002 tentang Perlindungan Anak ("UU Perlindungan Anak"), Pasal 5, yang berbunyi: "Setiap anak berhak atas suatu nama sebagai identitas diri dan status kewarganegaraan."

Kemudian, ketentuan hukum yang mengatur mengenai pemberian nama di Indonesia dapat ditemukan pada Kitab Undang-Undang Hukum Perdata("KUHPer"), Buku Kesatu Bab II Bagian ke-2 tentang Nama-nama, perubahan nama-nama, dan perubahan nama-nama depan,yaitu mulai Pasal 5a s.d. Pasal 12. Di dalam Pasal 5a KUHPer disebutkan bahwa: "Anak sah serta anak tidak sah tetapi diakui oleh bapaknya, berhak menggunakan nama keturunan bapaknya. Jika anak tidak sah tidak diakui oleh bapaknya, maka memakai nama keturunan ibunya."

Menteri Dalam Negeri dengan Surat Nomor: Akta 474.1/1580/SJ Tahun 2003 Perihal Pencantuman Nama Keluarga Dalam Pencatatan Kelahiran mengatur penggunaan nama keluarga/marga/keturunan, "Pencantuman nama keluarga/marga/keturunan di belakang nama kecil dapat dipergunakan apabila ada yang meminta, dengan persyaratan bahwa pencantuman nama keluarga/marga/keturunan tersebut dilakukan melalui pembuktian hukum keturunan." 
Di luar itu, peneliti belum menemukan ketentuan perundang-udangan yang mengatur pemberian nama anak maupun yang melarangnya. Hanya saja, orang tua diharapkan tetap memperhatikan salah satu prinsip dasar Konvensi Hak-Hak Anak sebagaimana diatur Pasal 2 huruf b UU Perlindungan Anak, yaitu kepentingan terbaik bagi anak. Lebih jauh, di dalam Penjelasan Umum UU Perlindungan Anak ditegaskan bahwa orang tua bertanggung jawab untuk menjamin pertumbuhan dan perkembangan anak, baik fisik, mental, spiritual maupun sosial. Berdasarkan hal itu, berarti orang tua punya tanggung jawab untuk memberikan nama yang terbaik bagi anak. Hal ini diharapkan dapat menimbulkan kepercayaan diri kepada anak, sehingga anak dapat mengembangkan segala potensi dan bakat yang dimilikinya semaksimal mungkin.

Untuk nama orang, juga tidak termasuk yang dilindungi undang-undang HAKI. Tidak ada hak paten untuk nama orang. Itu artinya setiap orang atau setiap warga negara Indonesia berhak memilih dan menggunakan nama yang dinilai baik dan disukai untuk diberikan pada anaknya, sekalipun nama tersebut sama dengan nama orang lain, bahkan nama presiden sekalipun. Dari dasar-dasar hukum dan ketentuan perundang-undangan di atas, Tuhan di Jember tidak melakukan pelanggaran hukum sama sekali. Haknya menggunakan nama juga dilindungi undang-undang.

\section{Kajian Etimologi dan Morfologi}

Dalam kajian ini peneliti menelusuri asal usul kata Tuhan dan proses perubahan kata tersebut beserta makna dan pergeseran pemaknaannya. Dari penelusuran berbagai literatur, penulis menemukan akar permasalahannya, sebagai titik awal untuk mengurai permasalahan ini. Pertama, orang Indonesia pascakolonial hanya tahu bahwa Tuhan adalah "God". KBBI juga memberi divinisi Tuhan adalah sesuatu yang diyakini, dipuja, dan disembah oleh manusia sebagai yang Mahakuasa, Mahaperkasa (God). Dengan pengetahuan kolektif masyarakat Indonesia ini, maka ketika disebut nama Tuhan yang muncul dalam pikiran adalah yang Mahakuasa, yang Maha Esa, sesembahan mereka. Masyarakat tidak bisa menerima ketika menemukan kenyataan ada manusia biasa yang bukan 
sesembahan, tidak memiliki keagungan, tidak memiliki kekuasaan dan kekuatan besar terhadap mereka, menggunakan nama Tuhan.

Sementara dalam kesusasteraan Jawa kuno Tuhan itu bisa berarti "master, lord, person in authority; also used in addressing a woman (the wife, the beloved) or a child" (Old Javanese - English Dictionary, P.J Zoetmulder:1982). Jadi menurut susastera Jawa kuno tersebut, kata Tuhan bukan hanya God, tapi juga bermakna tuan atau pemimpin, bahkan juga untuk menyebut perempuan (istri, kekasih) atau anak. Salah satu contoh kalimat yang menunjukkan Tuhan sebagai pemimpin adalah: "hana kawula hana tuhan" yang berarti "ada hamba ada paduka". Zoetmulder menyebutkan, kalimat itu terdapat dalam "Ślokāntara, an Old Javanese Didactic Text, critically edited and annotated" oleh Sharada Rani (New Delhi, 1957).

Di sisi lain juga ditemukan Tuhan yang bermakna ilahiah, bukan insani, dalam Tantu Panggelaran: Mwajar ta bhatara Guru: "Uni haku duk pinaka [gurunikang rat kabeh, duk] guru ning dewata kabeh, bhatara Guru haranku. Mangke pwaku hamahayu rat kabeh; "Tuhan, rahadyan, Pangeran" hujar ning wwang kalaran masambat iryyaku. Matangnyan bhatara Tuhan ngaranku, aku bhatara Pangeran, aku kinabhaktyan ikang manusa." Terjemahannya menurut Dwi Ratna Nurhajarini dan Suyami (1999), Berkatalah Bathara Guru, "Dulu aku ketika sebagai guru seluruh alam semesta, ketika sebagai guru bagi semua dewa, sebutanku Bathara Guru. Sekarang aku mengatur kebaikan seluruh alam semesta "Tuhan, Rahadyan, Pangeran" perkataan orang-orang kesakitan berkeluh padaku. Oleh sebab itu, Bathara Tuhan sebutanku, aku Bathara Pangeran."

Tantu Panggelaran adalah naskah berbahasa Jawa pertengahan yang selesai ditulis tahun 1557 dan diterbitkan oleh Theodoor Gautier Thomas Pigeaud tahun 1924. Dari kalimat itu, terlihat Tuhan setara Rahadyan dan Pangeran. Rahadyan kemudian mengalami proses morfologi bentuk penggalan berubah jadi Raden. Kata Raden di Jawa kemudian lebih untuk gelar atau sebutan orang agung atau yang diagungkan, seperti raja dan keluarga besarnya. Dengan kata lain Raden untuk insaniah. Untuk Pangeran, orang Jawa sampai sekarang masih memakai Pangeran untuk sebutan manusia yang agung maupun yang diagungkan (insaniah) 
dan dzat ilahiyah. Contoh dzat ilahiah,"Apa jare Pengeran wae", artinya "apa kata Tuhan saja”. Untuk insaniah, contohnya Pangeran Diponegoro, Pangeran Samber Nyawa.

Menurut ahli bahasa Remy Sylado dalam tulisannya "Bapa Jadi Bapak, Tuan Jadi Tuhan, Bangsa Jadi Bangsat" (Kompas, 11 September 2002) kata Tuhan berasal dari tuan adalah ciptaan Melchior Leijdecker, pendeta tentara yang berlatar pendidikan kedokteran. Leijdecker memperkenalkan nama Tuhan sebagai ilahiah pada Injil yang diterjemahkannya dalam bahasa Melayu pada tahun 1733. Leijdecker juga menyematkan kata Tuhan pada Isa atau Yesus. Jadi, Yesus adalah tuan sekaligus Tuhan.

Sebelum tahun 1733 belum ditemukan keterangan tentang prasasti berbahasa Melayu kuno yang mengandung kata Tuhan (ilahiah). Dalam kamus komparatif bahasa-bahasa rumpun Austronesia, juga belum ditemukan kata Tuhan (ilahiah). Jadi kata Tuhan dikenal sebagai dzat ilahiah dalam bahasa Melayu, yang kemudian disepakati sebgai Bahasa Indonesia, diduga mulai tahun 1733. Tantu Panggelaran dikarang tahun 1557, Injil Melayu oleh Leijdecker tahun 1733, ada selisih 176 tahun. Ini menujukkan Tuhan insaniah lebih dulu hadir di khasanah budaya kita, disbanding Tuhan yang merujuk pada dzat ilahiah. Ada selisih sekita 176 tahun.

Buku pertama yang memberi keterangan tentang hubungan kata tuan dan Tuhan adalah adalah Ensiklopedi Populer Gereja oleh Adolf Heuken SJ (1976). Menurut buku tersebut, arti kata Tuhan ada hubungannya dengan kata Melayu tuan yang berarti atasan/penguasa/pemilik. Kata "tuan" ditujukan kepada manusia, atau hal-hal lain yang memiliki sifat menguasai, memiliki, atau memelihara. Digunakan pula untuk menyebut seseorang yang memiliki derajat yang lebih tinggi, atau seseorang yang dihormati. Penggunaannya lumrah digunakan bersama-sama dengan disertakan dengan kata lain mengikuti kata "tuan" itu sendiri, dimisalkan pada kata "tuan rumah" atau "tuan tanah" dan lain sebagainya. Bagi orang Jawa kuno, Tuhan yang insani dan Tuhan yang ilahi dipahami secara berbeda dan tegas. Tuhan insani bisa siapa saja sesuai konteksnya. Tuhan ilahi 
adalah Bathara Guru, dewa segala dewa, sebagaimana menurut Tantu Panggelaran tadi.

Kata yang mirip Tuhan juga ditemukan dalam naskah Sunda kuno oleh Bujangga Manik yang diperkirakan ditulis pada masa peralihan abad 15 ke 16 . Tohaan dalam bahasa Sunda kuno bermakna tuhan, sebagaimana Tuhan dalam Jawa kuno. Séok na janma nu carek: Tohaan na dék ka mana? Mana sinarieun teuing teka leu(m)pang sosorangan?. Terjemahannya; Banyak rakyat yang berkata: "Ke manakah engkau akan pergi, Tuan? Kenapa engkau tiba-tiba bepergian sendiri." Ditanya ha(n)teu dek nyaur. Nepi ka Pakeun Caringin, ku ngaing teka kaliwat. Terjemahannya ; Walau mereka bertanya, aku tidak ingin berkata apa-apa. Pergi ke Pakeun Caringin, aku melewatinya dengan segera.

Terjemahan Indonesia berasal dari http://bastiawanade.blogspot.com/ Sedangkan terjemahan Inggris oleh J. Noorduyn dalam "Bujangga Maniks journeys through Java; topographical data from an old Sundanese source" tahun 1982 seperti ini: People called to him: "Where are you going, my Lord? Why are you so unusually walking all alone?" Thus questioned he did not want to speak.

Pemerhati bahasa Ashari Mardjoeki berpendapat berbeda. Menurutnya kata Tuhan dalam bahasa Indonesia, berasal dari bahasa Jawa, yaitu dari kata"utuh" yang mendapat imbuhan "an" menjadi "utuh-an," yang memunyai makna "yang lengkap, yang sempurna, yang tidak kurang dan tidak ada lebih." (Kompasiana,Maret 2011, yang diperbarui: 26 Juni 2015)

Selanjutnya kata utuhan mengalami proses morfologi menghilangkan fonem "U" di depan menjadi kata "tuhan" yang dipakai dalam percakapan seharihari dalam Bahasa Indonesia. Kata "tuhan" digunakan untuk menyebut "keberadaan paling yang sempurna," yang disembah; yang dipatuhi; sesuatu yang senantiasa dituju, yaitu "kesempurnaan." Tempat manusia memohon kebaikan bagi dirinya.

\section{Kajian Lisan dan Semiotik}

Selain meneliti dengan pendekatan etimologi dan morfologi, peneliti juga menggunakan pendekatan kajian lisan untuk mengumpulkan informasi secara 
lisan dari masyarakat sekitar dan pemilik nama Tuhan, mencatat, dan kemudian mendiskripsikannya untuk memperoleh gambaran, baik kehidupan masa lalu maupun kehidupan masa kini dari orang-orang yang bernama Tuhan di Jember ini. Untuk keperluan ini, peneliti tidak turun langsung ke lokasi, tetapi meminta bantuan awak media jaringan Kompas Gramedia yang terdekat ke lokasi dan diperkaya hasil bacaan liputan berbagai media massa. Dari data yang peneliti dapat dan diskripsikan, kemudian peneliti menafsirkan dan maknainya dengan pendekatan semiotik.

Kehidupan pemilik nama Tuhan di Jember rata-rata hidup sederhana sebagai petani. Ia mengerjakan apa yang menjadi kebiasaan petani di pedesaan di Jember pada umumnya, seperti ke sawah atau tegal, mencangkul, mencari rumput dan memelihara ternak sebagai pekerjaan sampingan. Mereka juga bersosialisasi dengan masyarakat sebagaimana layaknya kehidupan bermasyarakat di pedesaan. Untuk kehidupan rumah tangga, pemilik nama Tuhan di Jember juga membangun rumah tangga, memiliki anak, istri dan cucu, seperti masyarakat pada umumnya. Dari segi kesehatan, mereka juga mengalami sakit. Bila sakit mereka juga membutuhkan obat dan dokter/bidan/mantri untuk menyebuhkan sakitnya.

Dari ketokohannya, dari lima orang Tuhan di Jember yang masih hidup tidak ada yang menjadi tokoh menonjol. Tidak ada yang memiliki kekuasaan yang luas. Rata-rata usianya sudah tua. Dari kecil sampai tua tidak terlihat ada upaya dari para pemilik nama Tuhan ini untuk menonjolkan diri atau membuat upayaupaya agar menjadi tokoh terkenal dan memiliki kekuasaan luas.

Salah satu pemilik nama Tuhan yang tinggal di Jalan Manyar, RT 001/RW 006, Lingkungan Krajan, Kelurahan Slawu, Kecamatan Patrang, Jember, saat ditemui koresponden peneliti terlihat berkeringan, kuyu dan capai. Saat itu Tuhan yang satu ini memang baru pulang dari sawah dan membawa rumput untuk pakan ternak yang dipeliharanya. "Istirahat, baru saja pulang dari sawah mencari rumput," katanya saat ditanya kegiatannya saat itu.

Pria kelahiran Jember, 26 Oktober 1950 itu mengaku tidak terbebani dengan nama Tuhan yang diberikan oleh orang tuanya. Ia merasa biasa saja. 
Warga di sekitarnya juga tidak pernah mempermasalahkan namanya. Sampai saat ditemui di rumahnya, Tuhan ini tidak terbersit keinginan untuk mengganti namanya. Ia juga berpadangan tidak ada pentingnya mengganti namanya atau menambah namanya. "Orang-orang tidak memanggil saya Tuhan. Manggilnya Pak Farida, karena anak saya namanya Farida," jelasnya.

Ia sendiri tak mempermasalahkan kalau ada orang yang heran setelah tahu namanya Tuhan. Hal itu sudah biasa dialaminya, terutama saat mengurus perihal administrasi kependudukan. Sebagian petugas ada yang heran, lainnya tersenyum, dan ada yang mengodanya untuk bercanda. Tuhan tidak merasa tersinggung ataupun terbenani mentalnya. "Biasa mawon," (biasa saja) katanya.

Tuhan yang satu ini mengaku tidak tahu apa alasan orang tuanya memberi nama Tuhan kepadanya, begitu juga dengan tujuannya. Tuhan tidak pernah mempertanyakan namanya itu kepada orang tuanya sewaktu orang tuanya masih hidup. Ia pakai saja nama itu, tanpa berusaha mengetahui maknanya dan maksud tujuan orang tuan memberi nama tersebut.

Dari data yang penulis kumpulkan dan diskripsikan tersebut, dilihat dari analisa pendekatan semiotik, tidak ada tanda-tanda para pemilik nama Tuhan di Jember ingin menjadi Tuhan sesembahan manusia. Tidak ada tanda-tanda ingin membangun kekuasaan, membangun pengaruh yang kuat dan luas. Tidak ada tanda-tanda untuk merendahkan atau menodai keagungan ilahiah Tuhan. Mereka juga tidak ada tanda-tanda secara sengaja belaku syirik kepada Tuhan. Mereka hanya sekedar menjalani kodratnya sebagai manusia biasa, yang merindukan bertemu Tuhan yang Maha Esa dan berharap bisa menghuni surga-Nya.

\section{Simpulan}

Makna nama Tuhan yang dipakai warga di Jawa Timur yang paling tahu makna sebenarnya adalah orang yang membuat atau memberi nama. Namun orang-orang tersebut sudah meninggal. Kita hanya bisa mencoba memaknai dan menafsirkan dengan kaidah-kaidah keilmuan yang empiris dan terukur.

Dilihat dari sisi hukum, tidak ada pelanggaran yang dilakukan oleh Tuhan di Jember. Sebagai warga negara Indonesia, mereka memiliki hak menggunakan nama tersebut dan dilindungi oleh undang-udang, sehingga tidak ada pihak lain 
yang berhak memaksa dan melarang mereka menggunakan nama Tuhan. Dilihat dari asal usul kata, Tuhan Jawa dan tohaan Sunda lebih tua daripada Tuhan Injil berbahasa Melayu, apalagi kita sebagai orang Indonesia. Untuk itu, kita sebagai orang Indonesia yang memiliki dan memakai nama Tuhan itu baru belakangan, seharusnya tetap menghormati yang lebih dahulu menggunakan nama Tuhan. Penulis memiliki keyakinan orang-orang tua di Jawa Timur tersebut menamai anaknya sebagai Tuhan sesungguhnya adalah ingin mewariskan bahasa leluhur sejati, sebuah keinginan yang luhur agar bahasa leluhurnya itu bisa dikenal dan dikenang generasi penerusnya. Tidak selayaknya si pemilik nama dipaksa mengubah nama, apalagi diboikot hak-hak sipilnya.

\section{Daftar Pustaka}

Heuken, Adolf (1976), Ensiklopedia Populer Gereja

http//Ranowijaya.blogspot.com/2009/3/etimologi.html. Diakses pada tanggal 19 http://bastiawanade.blogspot.com//. Diakses pada tanggal 18 Mei 2021 https://kbbi.kemdikbud.go.id/entri/Tuhan. Diakses 18 Mei 2021 https://nasional.tempo.co/read/694671/mui-jatim-minta-nama-tuhan-harusdiganti-atau-ditambah. Diakses 18 Mei 2021

https://www.komnasham.go.id/files/1475231474-uu-nomor-39-tahun-1999tentang-\%24H9FVDS.pdf. Diakses pada tanggal 18 Mei 2021 https://www.kompasiana.com/ashari/55011521a333111d72512749/terminologikata-tuhan-dalam-bahasa-indonesia. Diakses pada tanggal 18 Mei 2021 https://www.kompasiana.com/ashari/55011521a333111d72512749/terminologikata-tuhan-dalam-bahasa-indonesia. Diakses pada tanggal 18 Mei 2021 https://www.researchgate.net/publication/41017889_Bujangga_Manik's_journeys _through_Java_topographical_data_from_an_old_Sundanese_source Mei 2021

Nurharjarini, Dwi Ratna dan Suyami. (1999). Kajian Mitos dan Budaya dalam Tantu Panggelaran. Jakarta: Departemen Pendidikan dan Kebudayaan RI. 
Sylado, Remy. 2002. Bapa Jadi Bapak, Tuan Jadi Tuhan, Bangsa Jadi Bangsat. Kompas, 11 September 2002. 